Article

\title{
Gamified Wearable Fitness Tracker for Physical Activity: A Comprehensive Literature Review
}

\author{
Inje Cho ${ }^{1, *}$, Kyriaki Kaplanidou ${ }^{1}$ and Shintaro Sato ${ }^{2}$ (D) \\ 1 Department of Sport Management, University of Florida, Gainesville, FL 32611-8208, USA; \\ kkaplanidou@hhp.ufl.edu \\ 2 Faculty of Sport Sciences, Waseda University, 3-4-1 Higashifushimi, Nishi-Tokyo, Tokyo 202-0021, Japan; \\ satoshintaro@aoni.waseda.jp \\ * Correspondence: colincho88@ufl.edu
}

check for updates

Citation: Cho, I.; Kaplanidou, K.; Sato, S. Gamified Wearable Fitness Tracker for Physical Activity: A Comprehensive Literature Review. Sustainability 2021, 13, 7017. https:// doi.org/10.3390/su13137017

Received: 24 May 2021

Accepted: 17 June 2021

Published: 22 June 2021

Publisher's Note: MDPI stays neutral with regard to jurisdictional claims in published maps and institutional affiliations.

Copyright: (c) 2021 by the authors. Licensee MDPI, Basel, Switzerland. This article is an open access article distributed under the terms and conditions of the Creative Commons Attribution (CC BY) license (https:/ / creativecommons.org/licenses/by/ $4.0 /)$.

\begin{abstract}
Recently, gamified wearable fitness trackers have received greater attention and usage among sport consumers. Although a moderate amount of aerobic physical activity can significantly reduce the risk of many serious illnesses, physical inactivity issues are still prominent. Although wearable fitness trackers have the potential to contribute to physical activity engagement and sustainable health outcomes, there are dwindling engagement and discontinuance issues. Thus, examining its gamification elements and role in physical activity becomes critical. This study examined the gamification elements in wearable fitness trackers and their role in physical activity and sports engagement. A comprehensive literature review yielded 26 articles that empirically measured a variety of gamification features and the effect of the device on physical activity and sports engagement. The study suggests three key gamification themes: goal-based, social-based, and rewards-based gamification that can be a point of interest for future scholars and practitioners. Based on the review, we propose a conceptual framework that embraces motivational affordances and engagement in physical activity and sports.
\end{abstract}

Keywords: gamification; wearable technology; fitness tracker; physical activity; engagement

\section{Introduction}

Participating in physical activity (PA) has been found to benefit a person's health [1]. Nevertheless, physical inactivity can dominate a person's leisure time raising various health concerns. The Centers for Disease Control and Prevention [2] reported that more than onefourth of U.S. adults are physically inactive, which indicates they are not participating in moderate (e.g., 150 min of walking briskly a week) to vigorous PA (e.g., 75 min of running a week). As an intervention tool that enhances individual engagement in PA, information and communication technology (ICT) can play an important role. Recent studies have argued that technological interventions could result in higher PA level and active sports participation $[3,4]$.

Due to the rapid development of ICT, wearable fitness trackers (WFT) have received greater attention and usage among consumers. These can synchronously record various physiological data to help individuals monitor their workouts, stimulating motivation and enjoyment. The use of WFT has increased in popularity, and nearly $10 \%$ of Americans in 2018 reported that they had used the device [5]. Among various types of WFT, the usage of wrist-worn WFT (e.g., Apple Watch, Fitbit, Whoop, Suunto Watch) has been particularly been popular due to affordability, comfortability, along with a high level of customer satisfaction and acceptance [6]. Previously, scholars have started to accumulate evidence that wrist-worn WFT can contribute to active lifestyles [7-9].

Despite the increasing usage, one-third of WFT users in the U.S. had discontinued use within 6 months [10]. Such short-term use is unlikely to resolve physical inactivity issues and to promote sustainable lifestyle change. 
One of the benefits that consumers derive from wrist-worn WFT is gamified experiences with ease. Gamification, defined as the implementation of game design in a non-game context [11], has been suggested as an effective health intervention tool in multiple domains [12,13]. An embodiment of gamification in WFT motivates consumers to become more active and engaged $[12,14]$. Since individuals may confront internal (e.g., biological and psychological) and external (e.g., environmental and social) barriers while engaging in PA [15], gamified technologies could enhance the consumer experience by enabling additional motivators.

As more innovative WFTs continue being released every year with improved features and consumer experience [16], there is a need for research exploring the impact of gamification elements mounted in WFT on sport consumers. To leverage the positive impact of wrist-worn WFT on PA engagement and continuance, exploring what factors of wrist-worn WFT interface, especially gamification elements, becomes critical [9]. There is a strong need to assess the range of empirical PA studies and to improve the efficacy in increasing the use of ICT in sport studies that promote population health [3,17]. Identifying the empirical studies that have examined the role of gamified WFT, as motivational affordances of engagement in PA and sports can be a point of interest for future scholars and practitioners. By reviewing the literature, we specified the intrinsic and extrinsic motivational affordances of gamified WFT that have an influence on PA engagement. Based on our findings from the review, we present a conceptual framework that embraces three key gamification themes (i.e., goal-based, social-based, and rewards-based gamification), PA engagement, and sport participation.

\section{Literature Review}

\subsection{Gamification in Physical Activity}

"Play is older than culture" [18] (p. 1). Humans innately learn how to play games. Derived from the concept of play, games are at the very center of what makes us human. Meaning improvisational and boisterous, play (Paidia) has been evolved to game (ludus), which relates to contrivance and subordination to rules [19]. Characterized by definite rule systems and competition, a game enables people to strive toward goals. Games assist individuals in increasing the level of effort, skill, and ingenuity [19]. The first attempt to conceptualize gamification in the field was made by Deterding et al. [11], who defined gamification as:

The use (rather than the extension) of design (rather than game-based technology or other game-related practices), elements (rather than full-fledged games) and characteristic for games (rather than play or playfulness) in non-game contexts (regardless of specific usage intentions, contexts, or media of implementation) (p. 13).

Gamification has been adopted in many disciplines as a way of engaging individuals with PA $[20,21]$. Previous literature suggested various gamification elements that potentially contribute to enhancing PA and sport participation [13,17].

\subsection{Self-Determination Theory: Motivational Affordances}

To further enrich our understandings of gamification elements in WFT, it is imperative to pay attention to motivational affordances. Motivational affordances refer to users' perceptions about the possibilities that a focal technology can satisfy their basic psychological needs [22]. Self-determination theory [23] helps us understand how gamification elements of WFT and motivations are interrelated. According to Deci and Ryan [23], intrinsic motivation is related to autonomous and self-determined behavior of seeking rewards inherent in the task (e.g., enjoyment), whereas extrinsic motivation refers to behavior driven by external rewards. A presentation of automated data in WFT allows individuals to track their activity level, and it boosts inherent interest in PA. In contrast, external reward systems mounted in a device provide additional motivational affordances to its users [24]. As such, gamified WFT affects engagement levels by effectively stimulating intrinsic or extrinsic motivations. 
According to early work in many areas, gamification orientations are grouped into intrinsic and extrinsic motivational affordances [12,24-26]. By conducting a frequency analysis of survey responses, Kappen et al. [12] found that intrinsic gamification elements may include goals, challenges, progression, achievements, choice or options, quests, and social sharing. These elements affect an individual's PA engagement by promoting inherent interest in PA. Extrinsic elements (i.e., virtual rewards) are "digital or intangible incentives given following a desired response in an attempt to reinforce the response" [14] (p. 1708). These elements include badges, points, leaderboards, incentives, and rewards [25]. Overall, gamified interventions including self-regulation, socialization, and rewards are critical in providing an enjoyable PA experience [21].

Kappen and Nacke's [25] kaleidoscope of effective gamification illustrates how the two motivated behavior layers (i.e., intrinsic and extrinsic) are critical for effective gamification experiences. The authors argued that intrinsic motivation, along with competence, autonomy, and relatedness, needs to be integrated into extrinsic motivation, which is facilitated by external rewards. Nicholson [27] also suggested the two types of gamification: reward-based gamification and meaningful gamification. In rewards-based gamification, gamification systems rely upon a thin layer of game-like experience using rewards systems [27]. However, in meaningful gamification, the system helps people find meaningful associations with the given activities. The gamified system allows users to create their own goals, but to utilize rewards only when it is truly necessary for progress [27].

Based on previous literature in gamification and motivational affordances, we would like to further articulate the gamified elements in wrist-worn WFT and propose a conceptual framework that integrates PA and sports engagement. Although previous studies have attempted to specify the gamification elements by examining various types of technologies, there are still very limited studies exploring gamification elements in wrist-worn WFT. Given the lack of research evidence, the current study explored various disciplines and found most studies existed in health and technology-related fields.

Thus, this study examines the gamified elements of WFT that have an influence on PA and sports engagement by applying the concept of intrinsic and extrinsic motivational affordances [12,24-26]. The current literature review helps us understand gamification elements in WFT and future directions for utilizing gamified WFT to support participation in PA. By conducting a comprehensive literature review, we categorized gamified elements of WFT based on our understanding of motivational affordances.

\section{Methods}

A comprehensive literature review was conducted to find types of gamified WFT utilized in PA studies. We categorized each of the gamification elements in terms of different types and functions: goal-based, social-based, and rewards-based gamification. Databases we used for the literature search were (1) electronic databases in university library website, which include, but not limited to, APA PsycINFO, PubMed/Medline, Sport Discuss, Scopus, (2) reference lists of the relevant articles, and (3) hand-searching of key journals through Google Scholar. During the review process, both peer-reviewed journal articles and conference proceedings were reviewed. We searched for relevant studies published between 1 January 2000 and 31 December 2020, using the following search terms (abstract, title, equivalent subjects): [("gamification") AND ("fitness tracker" OR "activity tracker" OR "wearable device" OR "smartwatch") AND ("physical activity" OR "exercise" OR "sport" OR "fitness")].

1. During this article search process, the following inclusion criteria were used to screen the articles: (1) the papers in multiple domains that focus on the effect of gamified WFT on individual PA engagement; (2) the papers provide empirical evidence regarding the effect of gamified WFT on PA engagement; (3) the population of the study is either non-patients or patients who have general health issues related to physical inactivity (e.g., obesity and overweight), and (4) the papers examined individuals using wrist-worn WFT. 
2. We included studies that were written in English and published in the past 12 years (from January 2009 to October 2020). The keyword search yielded 585 articles from 27 electronic databases (Figure 1). After the database search, 94 articles were selected for full review. Then, 16 articles were identified and used for thematic analysis. Additionally, the reference lists from identified articles and Google Scholar were used to find additional articles. During the review process, both peer-reviewed journal articles and conference proceedings (i.e., full paper) were reviewed. Altogether, a total of 26 articles were used for our thematic analysis (Table 1).

Table 1. Summary of articles analyzed for the review.

\begin{tabular}{|c|c|c|c|c|c|}
\hline Article & Methods & Participant & Device & Gamification & $\begin{array}{l}\text { Gamification } \\
\text { Themes }\end{array}$ \\
\hline [28] & $\mathrm{RCT}^{\mathrm{a}}(72-\mathrm{h})$ & $\begin{array}{l}\text { Children aged } 9 \text { to } 13 \\
\text { in U.S. }(n=67)\end{array}$ & WFT (Fitbit) & $\begin{array}{c}\text { Goal setting, progress, } \\
\text { virtual dog, rewards, points }\end{array}$ & $\begin{array}{c}\text { Goal and rewards } \\
\text { based }\end{array}$ \\
\hline [29] & $\begin{array}{l}\text { NRCT }^{\mathrm{b}} \text { (baseline, } \\
4 \text {-week } \\
\text { intervention) and } \\
\text { semi-structured } \\
\text { interviews }\end{array}$ & $\begin{array}{l}\text { Fitness center } \\
\text { members and } \\
\text { students in Germany } \\
\quad(n=12)\end{array}$ & $\begin{array}{l}\text { WFT (Mi Band), } \\
\text { mobile app }\end{array}$ & $\begin{array}{c}\text { Progress, feedback, } \\
\text { trophies, goals, social } \\
\text { comparison }\end{array}$ & $\begin{array}{l}\text { Goal, social and } \\
\text { rewards based }\end{array}$ \\
\hline$[30]$ & $\begin{array}{l}\text { NRCT (4- week } \\
\text { intervention) and } \\
\text { survey }\end{array}$ & $\begin{array}{l}\text { Seniors in Germany } \\
\qquad(n=20)\end{array}$ & $\begin{array}{l}\text { WFT, mobile app } \\
\text { (fMOOC) }\end{array}$ & $\begin{array}{l}\text { Progress, badges (training, } \\
\text { steps, posts, likes), group } \\
\text { and individual competition }\end{array}$ & $\begin{array}{l}\text { Goal, social and } \\
\text { rewards based }\end{array}$ \\
\hline [31] & $\begin{array}{c}\text { RCT (24-week } \\
\text { intervention, } \\
\text { 12-week follow-up) }\end{array}$ & $\begin{array}{l}\text { Adults with body } \\
\text { mass index } \geq 25 \text { in } \\
\text { U.S. }(n=602)\end{array}$ & $\begin{array}{l}\text { WFT (Withings } \\
\text { Activite Steel) }\end{array}$ & $\begin{array}{l}\text { Support, collaboration, } \\
\text { competition }\end{array}$ & $\begin{array}{l}\text { Goal and social } \\
\text { based }\end{array}$ \\
\hline [32] & $\begin{array}{l}\text { RCT (2-day } \\
\text { baseline, 1-week } \\
\text { control session, } \\
\text { 1-week follow-up) }\end{array}$ & $\begin{array}{c}\text { Students and } \\
\text { professionals in } \\
\text { Switzerland }(n=36)\end{array}$ & $\begin{array}{c}\text { WFT (Fitbit), } \\
\text { mobile app } \\
\text { (Healthytogether) }\end{array}$ & $\begin{array}{c}\text { Progress (self, group), } \\
\text { social setting (competition, } \\
\text { cooperation, hybrid), } \\
\text { points, badges, group } \\
\text { messages }\end{array}$ & $\begin{array}{l}\text { Goal, social and } \\
\text { rewards based }\end{array}$ \\
\hline [33] & $\begin{array}{l}\text { NRCT (baseline, } \\
\text { 2-month } \\
\text { intervention) }\end{array}$ & $\begin{array}{l}\text { Overweight and } \\
\text { obese or healthy } \\
\text { college students in } \\
\text { U.S. }(n=12)\end{array}$ & $\begin{array}{l}\text { WFT (Fitbit), } \\
\text { mobile app (Fitbit), } \\
\text { Twitter }\end{array}$ & $\begin{array}{l}\text { Progress, twitter messages, } \\
\text { feedback, individual and } \\
\text { group challenges, } \\
\text { competition, prizes }\end{array}$ & $\begin{array}{l}\text { Goal, social and } \\
\text { rewards based }\end{array}$ \\
\hline$[34]$ & $\begin{array}{l}\text { Longitudinal } \\
\text { semi-structured } \\
\text { focus group }\end{array}$ & $\begin{array}{l}\text { Adolescents aged } 12 \\
\text { to } 14 \text { years in } \\
\text { Northern Ireland } \\
(n=19)\end{array}$ & WFT (Fitbit) & $\begin{array}{l}\text { Goal setting, progress, } \\
\text { feedback, competitions, } \\
\text { material rewards, } \\
\text { teamwork }\end{array}$ & $\begin{array}{l}\text { Goal, social and } \\
\text { rewards based }\end{array}$ \\
\hline [35] & $\begin{array}{l}\text { RCT (7-day } \\
\text { baseline, 100-day } \\
\text { intervention, } \\
\text { 3-month } \\
\text { follow-up) }\end{array}$ & $\begin{array}{l}\text { Members of } \\
\text { community-based } \\
\text { Facebook groups in } \\
\text { Australia }(n=301)\end{array}$ & $\begin{array}{c}\text { WFT (Zencro, } \\
\text { TW64S, } \\
\text { GENEActiv), } \\
\text { mobile app (Active } \\
\text { team }\end{array}$ & $\begin{array}{l}\text { Progress, social interaction, } \\
\text { social comparison, support, } \\
\text { newsfeed, challenges, } \\
\text { leaderboards }\end{array}$ & $\begin{array}{l}\text { Goal, social and } \\
\text { rewards based }\end{array}$ \\
\hline [36] & $\begin{array}{l}\text { In-depth } \\
\text { semi-structured } \\
\text { interview }\end{array}$ & $\begin{array}{l}\text { WFT users using a } \\
\text { device for at least } \\
\text { three months, mostly } \\
\text { from North America } \\
\text { and Europe }(n=30)\end{array}$ & WFT & $\begin{array}{l}\text { Accounting, getting credit, } \\
\text { goals, rewards, data } \\
\text { sharing, social effects }\end{array}$ & $\begin{array}{l}\text { Goal, social and } \\
\text { rewards based }\end{array}$ \\
\hline [37] & $\begin{array}{l}\text { NRCT (baseline, } \\
\text { each of } 22 \text { sessions } \\
\text { occurred to } 1 \text { to } 4 \\
\text { days per week) }\end{array}$ & $\begin{array}{l}\text { Elementary school } \\
\text { students in U.S. } \\
\qquad(n=6)\end{array}$ & WFT (Fitbit) & $\begin{array}{l}\text { Progress, goal setting, } \\
\text { feedback. }\end{array}$ & Goal based \\
\hline [38] & $\begin{array}{l}\text { RCT (baseline, } \\
\text { 3-month } \\
\text { intervention) }\end{array}$ & $\begin{array}{l}\text { Young adults aged } \\
18 \text { years in Finland } \\
\qquad(n=209)\end{array}$ & WFT (Polar Active) & Progress, progress feedback & Goal based \\
\hline [39] & $\begin{array}{l}\text { NRCT (10-day } \\
\text { intervention) }\end{array}$ & $\begin{array}{l}\text { Seniors over } 50 \text { years } \\
\text { old in U.S. }(n=12)\end{array}$ & $\begin{array}{l}\text { WFT (Fitbit), } \\
\text { website }\end{array}$ & $\begin{array}{c}\text { Progress, monetary } \\
\text { rewards }\end{array}$ & $\begin{array}{c}\text { Goal and rewards } \\
\text { based }\end{array}$ \\
\hline$[40]$ & $\begin{array}{l}\text { Survey and focus } \\
\text { group }\end{array}$ & $\begin{array}{c}\text { WTF users (survey: } \\
n=47 \text {, focus group: } \\
n=7 \text { ) }\end{array}$ & WFT & $\begin{array}{l}\text { Progress, challenges, } \\
\text { competition, leaderboard, } \\
\text { rewards/badges, } \\
\text { socialization }\end{array}$ & $\begin{array}{l}\text { Goal, social and } \\
\text { rewards based }\end{array}$ \\
\hline
\end{tabular}


Table 1. Cont

\begin{tabular}{|c|c|c|c|c|c|}
\hline Article & Methods & Participant & Device & Gamification & $\begin{array}{l}\text { Gamification } \\
\text { Themes }\end{array}$ \\
\hline$[41]$ & $\begin{array}{l}\text { RCT (1-week } \\
\text { baseline, } 4 \text {-week } \\
\text { intervention) }\end{array}$ & $\begin{array}{l}\text { mActive enrolled } \\
\text { smartphone users } \\
\text { aged } 18 \text { to } 69 \text { years } \\
\text { in U.S. }(n=48)\end{array}$ & $\begin{array}{l}\text { WFT (Fitbug Orb) } \\
\text { and smartphone }\end{array}$ & $\begin{array}{l}\text { Progress, feedback } \\
\text { (smart texts) }\end{array}$ & Goal based \\
\hline$[42]$ & Survey & $\begin{array}{l}\text { WFT users in online } \\
\text { communities (North } \\
\text { America, Australia, } \\
\text { Europe) }(n=210)\end{array}$ & WFT & Progress, points & Goal based \\
\hline$[43]$ & $\begin{array}{c}\text { RCT (2-week } \\
\text { baseline, 12-week } \\
\text { intervention, } \\
\text { 12-week follow-up) }\end{array}$ & $\begin{array}{l}94 \text { families in U.S. } \\
(n=200 \text { adults })\end{array}$ & $\begin{array}{l}\text { WFT (Fitbit), } \\
\text { mobile app } \\
\text { (Moves, ProtoGeo } \\
\text { Oy or Fitbit) }\end{array}$ & $\begin{array}{l}\text { Progress, feedback, } \\
\text { collaboration, peer support, } \\
\text { points, levels }\end{array}$ & $\begin{array}{l}\text { Goal, social and } \\
\text { rewards based }\end{array}$ \\
\hline$[44]$ & $\begin{array}{c}\text { RCT (2-week } \\
\text { baseline, } 24 \text {-week } \\
\text { intervention, } \\
\text { 12-week follow-up) }\end{array}$ & $\begin{array}{l}\text { Overweight and } \\
\text { obese employees in } \\
\text { U.S. }(n=602)\end{array}$ & $\begin{array}{l}\text { WFT (Withings } \\
\text { Activité Steel) }\end{array}$ & $\begin{array}{l}\text { Progress, team competition, } \\
\text { support, collaboration, } \\
\text { point, level }\end{array}$ & $\begin{array}{l}\text { Goal, social and } \\
\text { rewards based }\end{array}$ \\
\hline [45] & $\begin{array}{l}\text { Semi-structured } \\
\text { interviews and } \\
\text { survey }\end{array}$ & $\begin{array}{l}\text { Colleagues, friends, } \\
\text { WFT users in social } \\
\text { media mostly reside } \\
\text { in U.S. and Germany } \\
\qquad(n=689)\end{array}$ & WFT & $\begin{array}{l}\text { Progress, challenges, social } \\
\text { contacts, entertainment, } \\
\text { rewards }\end{array}$ & $\begin{array}{l}\text { Goal, social and } \\
\text { rewards based }\end{array}$ \\
\hline [46] & $\begin{array}{l}\text { RCT (baseline, } \\
\text { 8-week } \\
\text { intervention) }\end{array}$ & $\begin{array}{l}\text { College students } \\
\qquad(n=40)\end{array}$ & $\begin{array}{l}\text { WFT (Jawbone } \\
\text { UP24) }\end{array}$ & $\begin{array}{l}\text { Interaction, social sharing, } \\
\text { feedback, goal setting, } \\
\text { challenges }\end{array}$ & $\begin{array}{l}\text { Goal and social } \\
\text { based }\end{array}$ \\
\hline [47] & $\begin{array}{l}\text { Phase 1: RCT } \\
\text { (6-week } \\
\text { intervention), } \\
\text { Phase 2: NRCT } \\
\text { (6-week } \\
\text { intervention) }\end{array}$ & $\begin{array}{l}\text { Medical residents in } \\
\text { U.S. }(n=104)\end{array}$ & WFT (Fitbit) & $\begin{array}{c}\text { Progress, feedback, team } \\
\text { competition, monetary } \\
\text { rewards }\end{array}$ & $\begin{array}{l}\text { Goal, social and } \\
\text { rewards based }\end{array}$ \\
\hline [48] & $\begin{array}{l}\text { RCT (2-week } \\
\text { baseline, 2-week } \\
\text { intervention, } \\
\text { 2-week follow-up) } \\
\text { and interviews }\end{array}$ & $\begin{array}{l}\text { Students and } \\
\text { employees in } \\
\text { Canada }(n=23)\end{array}$ & $\begin{array}{c}\text { WFT (Fitbit), } \\
\text { mobile app (Fitpet) }\end{array}$ & $\begin{array}{l}\text { Goal setting, progress, } \\
\text { social interaction (cheer-up, } \\
\text { nudge, conversation), } \\
\text { Fitpet (mini game, } \\
\text { accessories) }\end{array}$ & $\begin{array}{l}\text { Goal and social } \\
\text { based }\end{array}$ \\
\hline [49] & $\begin{array}{c}\text { RCT (2-week } \\
\text { baseline, 1-week } \\
\text { intervention, } \\
\text { 1-week of } \\
\text { follow-up) and } \\
\text { semi-structured } \\
\text { interview }\end{array}$ & $\begin{array}{c}\text { Employees in } \\
\text { Netherlands }(n=60)\end{array}$ & $\begin{array}{l}\text { WFT (Philips } \\
\text { Health Watch) }\end{array}$ & $\begin{array}{l}\text { Progress, personalized and } \\
\text { context-aware coaching } \\
\text { messages in real-time }\end{array}$ & Goal based \\
\hline$[50]$ & $\begin{array}{l}\text { RCT (10-day } \\
\text { baseline, 20-day } \\
\text { intervention) }\end{array}$ & $\begin{array}{c}\text { Fitbit users and } \\
\text { non-users }(n=54)\end{array}$ & WFT (Fitbit) & $\begin{array}{c}\text { Progress, social interaction } \\
\text { (messages, comments), } \\
\text { social game (steps as } \\
\text { currency) }\end{array}$ & $\begin{array}{l}\text { Goal, social and } \\
\text { rewards based }\end{array}$ \\
\hline [51] & $\begin{array}{l}\text { NRCT (1-week } \\
\text { baseline, 1-week } \\
\text { intervention, } \\
\text { 1-week follow-up) }\end{array}$ & $\begin{array}{l}\text { Adults in U.S. } \\
\quad(n=11)\end{array}$ & $\begin{array}{l}\text { WFT (Fitbit), } \\
\text { website }\end{array}$ & $\begin{array}{l}\text { Progress, prize draws } \\
\text { (verbal praises, small } \\
\text { prizes, prizes up to } \$ 15, \$ 50 \text {, } \\
\$ 120 \text { ) }\end{array}$ & $\begin{array}{c}\text { Goal and rewards } \\
\text { based }\end{array}$ \\
\hline [52] & $\begin{array}{l}\text { RCT (baseline, } \\
\text { 1-month } \\
\text { assessment, } \\
\text { 3-month } \\
\text { assessment) }\end{array}$ & $\begin{array}{c}\text { African American } \\
\text { women aged } 18 \text { to } 35 \\
\text { years in U.S. }(n=91)\end{array}$ & $\begin{array}{l}\text { WFT (Fitbit), } \\
\text { mobile app } \\
\text { (PennFit) }\end{array}$ & $\begin{array}{l}\text { Progress (self, group), } \\
\text { online group chatting }\end{array}$ & $\begin{array}{l}\text { Goal and social } \\
\text { based }\end{array}$ \\
\hline [53] & Survey & $\begin{array}{l}\text { WFT users at } \\
\text { worldwide } \\
\text { technology company } \\
\text { located in U.S. } \\
(n=238)\end{array}$ & WFT & $\begin{array}{l}\text { Social sharing (running } \\
\text { trajectory, comments, } \\
\text { leaderboards) and social } \\
\text { competing (friendly } \\
\text { competition, team } \\
\text { challenges, badges). }\end{array}$ & $\begin{array}{l}\text { Goal, social and } \\
\text { rewards based }\end{array}$ \\
\hline
\end{tabular}

${ }^{\mathrm{a}} \mathrm{RCT}=$ Randomized control trial, ${ }^{\mathrm{b}} \mathrm{NRCT}=$ Non-randomized trial. 


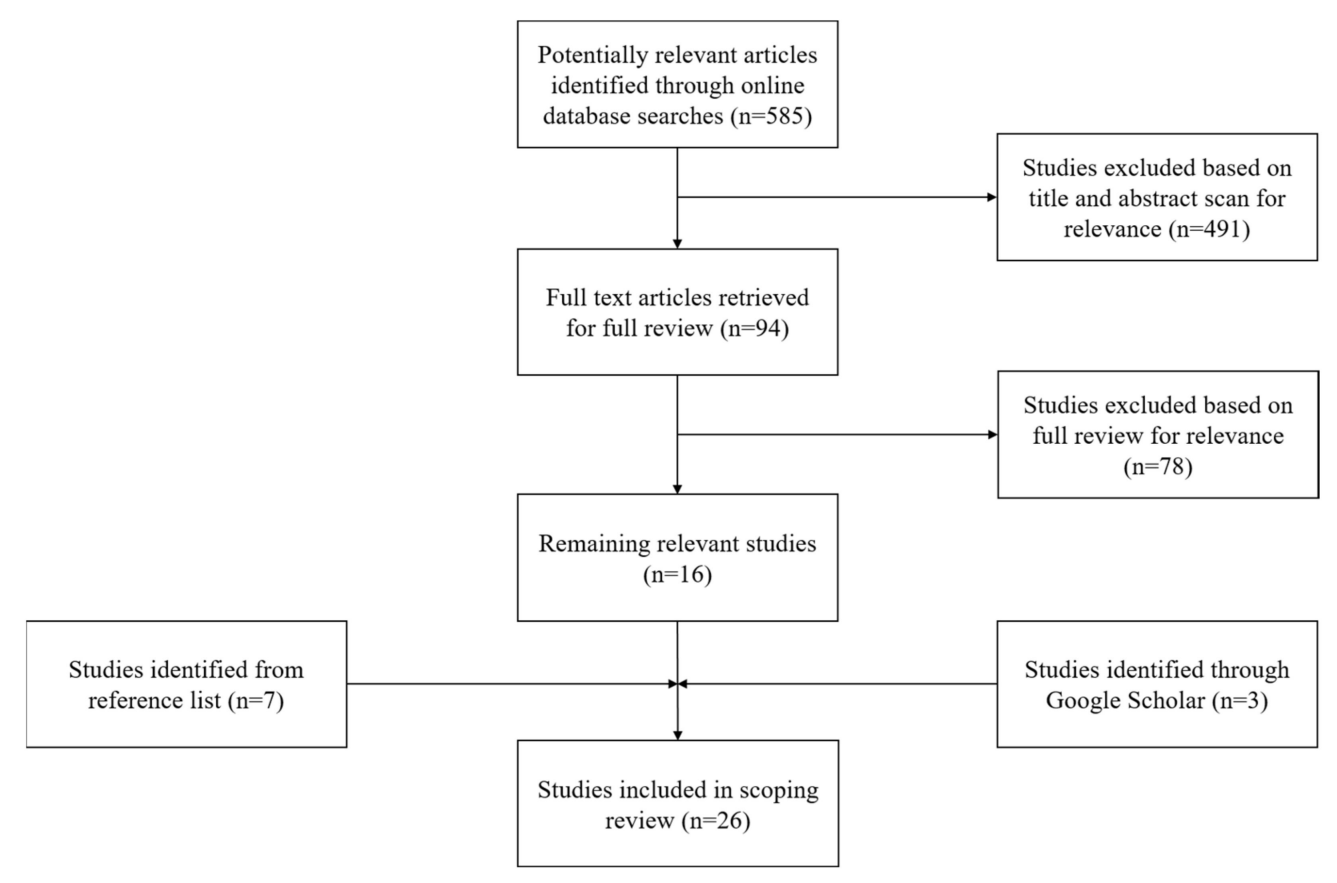

Figure 1. Review process of the literature review.

\section{Findings}

Based on theoretical background regarding gamification and motivational affordances $[12,23,25,26]$, we embarked on a thematic analysis to explore the types of WFT gamification. Our study observed three gamification themes: goal-based, social-based, and rewards-based gamification. These gamification elements are connected to two motivational affordances: intrinsic and extrinsic motivational affordances. Specifically, goal-based gamification is closely related to intrinsic motivational affordance, whilst rewards-based gamification is associated with extrinsic motivational affordance. Social-based gamification was classified as both intrinsic and extrinsic due to the nature of certain social activities as explained below. Our thematic analysis indicated that all studies included goal-based gamification strategies. Among them, five studies used a single strategy only, but the rest of the studies used a mix of gamification elements.

\subsection{Goal-Based Gamification}

People strive toward goals due to the psychological process of self-regulation [54]. One of the important aspects of engagement is whether individuals can use self-regulatory strategies to plan and evaluate their own work [55]. Since PA is a goal-driven behavior, individuals are exposed to a process of goal setting. Gamified WFT allows individuals' access to their goal assignment and guides individual PA while performing as reference points and self-incentives in a cognitive process [56]. Our findings identified that all of the reviewed studies included goal-based gamification strategies: goal setting and self-monitoring.

WFT users engage in constant self-monitoring of progress and achievements. To a great extent, the availability of physiological data is what makes gamified WFT valuable [57]. According to Consolvo et al. [58], knowing PA progress can be a significant motivator to increase self-efficacy and PA retention. Some of the previous studies indicated that access to PA performance information could make a difference. In Nelson et al.'s study [42], the self-regulation theory was used to explain how individuals set their goals and respond to feedback of achieving those goals. Nelson et al. demonstrated that visible change in individual progress (e.g., points and percentages) was the best predictor of an individual's health empowerment. Health empowerment is defined as the belief that a person has a significant effect over the ability to perform a health-related task [42]. 
As one of the three basic human needs, competence is about feeling confident in one's actions by exercising and expanding one's capacities [59]. Challenge and achievements are intrinsic motivators that trigger task-oriented motivation [24,45]. Goal-based gamification strategies aim to motivate individuals' desire to seek challenges and extend their physical and psychological capacities. Gamified WFT provides doable tasks and incremental challenges while participants engage in PA (Johnson et al., 2016). By using a goal setting mechanism, WFT assists people in obtaining competence with certain knowledge and skills. Schaffarczyk and Ilhan [45] found that gamified WFT helped participants feel high levels of physical aliveness, motivation to use WFT, and motivation to take part in future challenges. Winning a challenge was also found to be a strong reason for participants to engage in PA [45].

Nelson et al. [42] noted "With the aid of the device's goal settings and feedback mechanisms, an individual feels competent to define and impact their self-made goals" (p. 365). This quote alludes to the important role of WFT's automated feedback on PA engagement. Technology-assisted feedback was suggested as a booster for a healthy lifestyle [53,56]. In Martin et al.'s study [41], participants who received feedback about their progress showed higher increases in their daily step count than those in the no feedback condition and no progress condition. By conducting a focus group with young adolescents in Northern Ireland, [34] demonstrated that providing positive feedback when goals were met was critical in enhancing PA engagement. Further, receiving positive feedback could lessen the negative attitude created due to not winning external rewards (e.g., prizes). This finding was similar to previous meta-analysis work [60] that found that giving feedback on PA performance was the most effective intervention tool in increasing self-efficacy, which also leads to increased participation in PA. The results of some reviewed studies showed that utilizing goal-based strategy was not able to affect PA outcome significantly $[38,47]$. For instance, Thorndike et al. [47] found that feedback from WFT did not result in increased PA levels compared to a no feedback condition. In a 3-month randomized controlled trial, Jauho et al. [38] also found that feedback and progress resulted in a short-term but not significant effect on PA. Thus, most of the reviewed studies utilized goal-based gamification as a basis for participants using WFT.

\subsection{Social-Based Gamification}

Individuals are grounded in a social system, which allows them to engage in a sociocultural process that embraces cognitive learning, observation, and memory [56]. Bandura suggested that exposure to an activity creates a level of awareness that can build a stronger sense of self and contribute to the formation of positive behaviors in the long run. Several studies found that individuals shape their attitude toward PA differently based on the recognition of their social environment $[32,43,44,48,52]$. By engaging in a group-based activity, participants can fulfill the needs of competence and relatedness [24]. When people connect and have a sense of belonging, their intrinsic motivation grows stronger [59]. By providing a platform of social interaction, social-based gamification could serve as an intrinsic motivator to engage in the activity. When people engage in PA with others, but their behaviors are still determined by their inherent interest in PA, social-based gamification (i.e., teamwork, social sharing) promotes intrinsic motivation. On the contrary, social-based gamification can also become extrinsic motivational affordance [12]. When the social interaction platform becomes the primary reason for participating in PA and participant behaviors are driven by social rewards (e.g., leaderboards, recognition among participants), their intrinsic interests in PA are interrupted.

Social-based gamification theme includes collaboration, cooperation, sharing, competition, and recognition. Firstly, several studies found that collaboration and teamwork were common methods in social-based gamification [31,34,43,44]. Engaging in a group-based PA, individuals learn how to set health goals and interact with peers. Participants in collaborative settings become responsible to the group members. This setup induces a teamwork effort to meet assigned PA goals [33,43,44]. Patel et al. [44] compared the different effects 
of collaborative, competitive, and supportive interventions on the PA performance for a 24-week intervention and 12-week follow-up. In the collaboration setting, participants worked toward a group goal, while in the supportive group members could receive support from an acquaintance outside the experiment group. They found participants in the collaborative setting scored the lowest PA performance compared to participants in the other two interventions. Corepal et al.'s [34] interviews with teenagers also found that many barriers exist in team collaboration (e.g., free-riding teammates).

A cooperative environment can significantly affect an individual's PA engagement $[48,53]$. Although testing different effects of three gamification approaches, Tong et al. [48] found that a combination of social interaction and goal setting was a more effective PA intervention tool than a goal setting condition or a combination of goal setting and mobile app. Chen and Pu [32] also found a significant role of others' feedback on an individual's active participation in PA. In Chen and Pu's study, there was a positive correlation between the number of messages and PA performance. Using different gamification settings: competition, cooperation, and hybrid setting, Chen and $\mathrm{Pu}$ demonstrated that there was a significant PA increase in both cooperation and hybrid settings. In Zhang and Jemmott III's study [52], the treatment group that was allowed to chat with one another had better odds of meeting the goal than those who did not have the option to chat. During the three months of the experiment, steps, minutes of PA, and PA performance increased for the gamification intervention group.

Social sharing is the act of disclosing tracking data and exercise with others $[29,53]$. Sharing allows disclosure of physiological data, as well as individual feelings about PA either in collaborative or competitive social settings (Chen and $\mathrm{Pu}$, 2014). Participants in social group settings can be stimulated by observing others' PA performances and posts from others. These observations could increase individuals' goal achievement and their PA engagement. For instance, the ability to monitor other members' progress was a key component in a small-group intervention study [29,46,52]. Although Altmeyer et al. [29] found the PA level was significantly higher in the public display and app intervention group than the group that only used the app, Seo et al. [46] found a significant improvement in the connected group. A display of PA level could provide a place for socialization as well as a motivation to self-present the performance to receive some social recognition [29].

Human cognition evolves mainly in response to the challenging demands that exist in a social environment [56]. Social competition has been incorporated into gamification design in various studies $[34,43,44,48,53]$. Competitive social settings can be related to humans need to seek social recognition and status [61]. This social desire can be a primary motive for some participants and can lead to healthy relationships. In Buchem et al.'s study [30], a competition was the most popular gamification element for senior participants. Similarly, team competition groups recorded more steps than those in an individual condition [47]. Furthermore, leaderboards and newsfeeds can serve as gamification tools that display PA performance rankings, which provide a competitive platform among participants [35].

\subsection{Rewards-Based Gamification}

A rewards-based gamification strategy was common in many studies. External rewards were not independently used in the studies, but were incorporated with other gamification strategies. These rewards-based gamification strategies included virtual rewards (e.g., badges) and monetary rewards (e.g., prizes). In reviewed studies, rewards were found to be used as a booster for other types of gamification strategies. For instance, badges and points are grounded in some WFT (e.g., Fitbit). These incentives were given to participants as compensation for achieving individual progress [28,44] or socialization goals $[30,32]$. By providing an equal amount of external rewards to the three different social intervention groups, Chen and Pu tested the effect of social interaction on PA engagement level. Although conducting a non-randomized trial study with seniors in Germany, Buchem et al. [30] found that half of the participants were motivated by badges (e.g., steps, likes, posts) to engage in PA. 
In Patel et al.'s study [43], participants were randomized into two groups. This study used a combination of rewards-based and social-based rewards. Although a control group received individual feedback on goal performance by text message or e-mail, an intervention group received feedback with extra points and badges with support from family members. In the intervention group, participants entered into a game with their family, and the family was endowed with points. Thus, this group could receive more social incentives by collaborating, supporting, and taking responsibilities. When the goal was accomplished, participants received extra points at the end of the week to advance up to the next level (bronze, silver, gold, and platinum). Patel et al. found that the intervention group showed a significant increase in PA engagement compared to the control group. Overall, external rewards, such as points, rewards, levels, and badges, have great potential to improve individual health [13]. Sometimes, losing points is more effective in increasing motivation than gaining [43]. However, Corepal et al.'s finding [34] suggested that prompt rewards assist individual PA engagement, but failing to win a prize led to feelings of disappointment and reduced motivation.

Some studies also introduced monetary rewards as the main source of intervention. For instance, when conducting a non-randomized trial with older people in the U.S., Kurti and Dallery [39] found that participants' steps increased significantly at the intervention stage when monetary incentives were provided, but noticeably dropped when they were not provided. In Ahn et al.'s study [28], children in a no-points condition indicated higher levels of vigorous intensity PA than those in a points condition. Similarly, when prize draws were provided, a few participants showed a noticeable increase, and others showed modest improvements in average steps [51]. Likewise, when rewards become the main engagement tool in health intervention, it did not lead to a higher PA engagement [28,47].

\subsection{Conceptual Framework}

Based on the categorization of gamification in previous studies [12,24,25,27], as well as the findings from our literature review, we propose a framework for the gamified WFT motivational affordances (Figure 2). Goal-based gamification is considered intrinsic motivational affordances of gamified WFT, while rewards-based gamification features extrinsic motivational affordances. Social-based gamification can be either an intrinsic or extrinsic motivator for PA participants [12]. Based on the findings from the review, we propose a framework and next research steps that elaborate suggestions to utilize gamified WFT in sport studies.

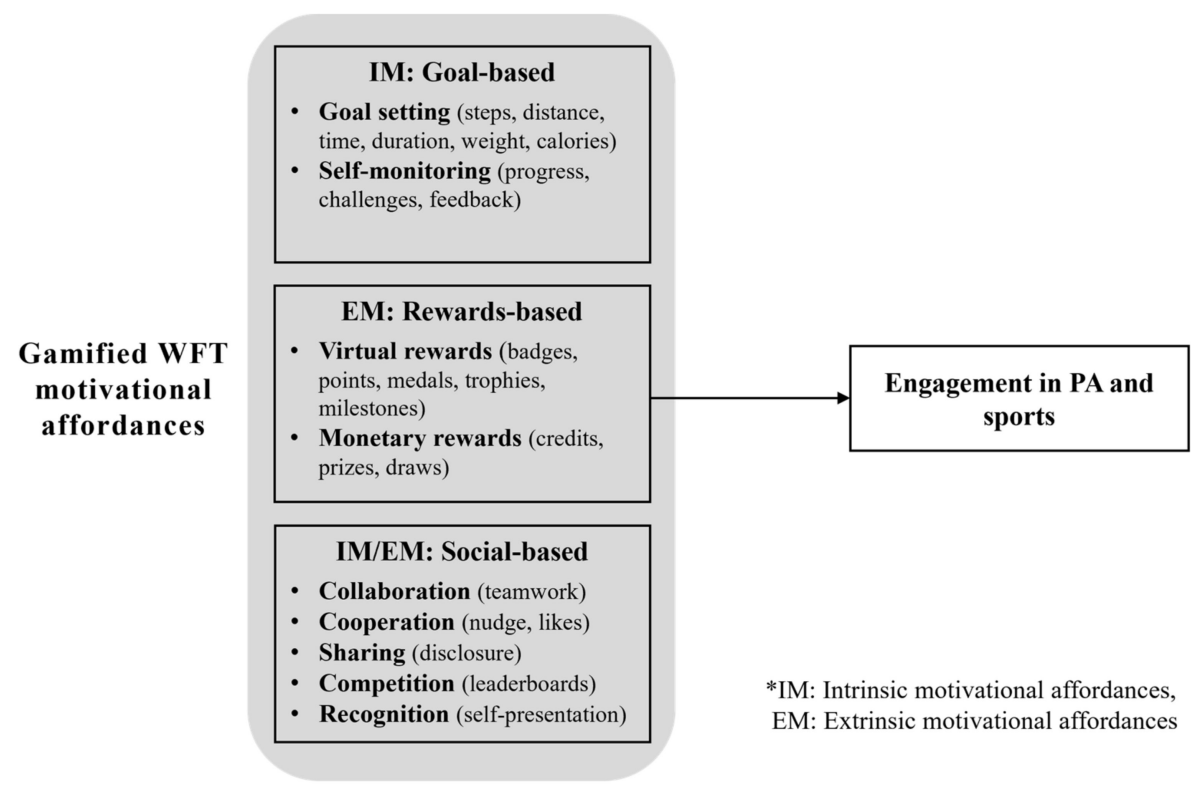

Figure 2. A framework for the gamified WFT motivational affordances. 


\section{Discussion}

WFT changes the way we engage in PA. However, limited attention has been paid to WFT in a management perspective $[17,62]$. To address the gap in the literature, the main purpose of this study was to explore the gamification elements in WFT and their effects on engagement in PA and sports. As potential antecedents of the engagement, we found three main gamification themes: goal-based, social-based, and rewards-based. This study proposes a conceptual framework that embraces gamified WFT and engagement in PA and sports.

The gamification themes were used in the reviewed studies as engagement factors that resulted in certain levels of activity engagement. Our thematic analysis supports previous arguments that individuals can fulfill inherent needs through self-regulation, socialization, and rewards [21,24]. Paired with our findings related to the types of gamification themes, SDT could provide a useful framework for predicting PA and sports engagement as each theme tied to a type of motivation found within SDT. As self-achievement is acquired through progress, goal setting is the primary method for regulating motivation and behavioral change [48]. As an intrinsic motivator, goal-based gamification elements in WFT help users set their optimal goals of steps, distance, time, duration, weights, and calories. If human needs are satisfied, people engage in learning while their enjoyment of the task and intrinsic motivation for the task increase [24]. That is, gamification elements in WFT could be adopted to offer individual feelings of competence, autonomy, and relatedness [7] and to enhance an individual's enduring engagement and PA performance outcomes [63].

Social incentives are also common in many reviewed studies. Our findings suggest that many social-based gamification elements affect individuals' PA engagement. This finding supports previous studies, which suggested that a sense of belongingness and camaraderie among the group can affect emotional engagement in the activity [64]. Our findings from Altmeyer et al. [29] and Seo et al. [46] support the previous study which demonstrated that participants who could share their PA performance were much more likely to reach their goal than isolated individual groups [58]. Additionally, cooperation [32,48,52] and competition $[30,44,47]$ were also found to be effective in PA engagement. Although a cooperative gamified environment helps individual learn and observe others while fulfilling the needs of relatedness [24,56], competitive social settings aspire individuals to seek social recognition and status [61].

Some of the reviewed studies found an unreliable effect of external rewards on sustainable engagement $[28,34,35,51]$. This finding contributes to an ongoing debate about the undermining effect of external rewards on the level of intrinsic motivation $[7,65]$. Previous literature also pointed out potential detrimental effects of gamified WFT on PA engagement and intrinsic motivation [7,14]. Through focus groups and a survey, Kerner and Goodyear (2017) tested whether WFT increases adolescents' level of motivation for PA. The study identified significant declines in levels of competence, autonomy, relatedness, and need satisfaction due to the use of WFT. These uncertainties about the impact of WFT on PA engagement corroborates the previous meta-analysis conducted by Deci et al. [65], which found an undermining effect of external rewards on intrinsic motivation. Although extrinsic rewards are present, people begin to feel controlled by the rewards, and the locus of causality is shifted from internal to external [65]. Thus, people who were given external rewards may be demotivated accordingly because the reward contingencies may preclude individuals' self-regulating behavior.

The thematic analysis indicated that only a few studies have used a single gamification element, while many incorporated two or more gamification strategies. This combination of different gamification strategies can lead to rigorous research design in health intervention studies. Our findings suggested that external rewards can be the basis of a gamification platform and they can be beneficial when they are combined with other gamification strategies. Applying Nicholson's [26] notion of a recipe for meaningful gamification, health intervention studies need to assure a number of factors that include storyline, exposition, and participant's freedom and choice, among others. By doing so, a gamification system 
could change a participant's sustainable and long-lasting attitude toward PA and sports, although the extrinsic rewards could fade away. Overall, researchers need to pay attention to the design of gamification studies, and how to consistently stimulate individual motivation, in particular. Extrinsic and intrinsic motivation should be theoretically embraced when examining ways to nurture sustainable engagement with PA and sports.

\section{Future Directions and Emergent Area of Research}

Our research findings suggest that future studies explore the various effects of the three different types of gamification on human basic needs. Each of the gamification themes (goal-, social-, rewards-based) may differently affect intrinsic and extrinsic motivation. The goal-based gamification strategy could target intrinsic motivation because it may affect mastery and skill improvement. The rewards-based gamification strategy performs as an extrinsic motivator since it provides monetary compensation and visible rewards in exchange for PA performance. The social-based gamification strategy serves as a booster of either intrinsic motivation or extrinsic motivation. When individuals' main motives to engage in PA are still inherent in the task, social affiliation and camaraderie are still intrinsic motivators. Otherwise, if individuals' primary purpose of PA becomes receiving recognition by others or outperforming others, social-based gamification could perform as an extrinsic motivator. Based on this proposition, future studies need to verify the role of the three different gamification themes on intrinsic and extrinsic motivation in different circumstances (e.g., primary motives) and also the emotional processes that emerge from the different types of motivation.

Although our suggested framework indicated gamification strategies' effect on PA engagement, there are also theoretical considerations in terms of identifying potential variables that connect to increasing PA and sport participation levels using gamification strategies as engagement factors. These variables could be related to intentions and behaviors to continue exercising and quality of life improvements. Future research needs to focus on testing the relationships between gamification and observable effects related to psychological mechanisms (e.g., self-efficacy) by using different gamification design elements [24].

There is a strong need to conduct health intervention studies for sport participants based on a comprehensive framework. Previous studies argued that researchers need to investigate the evidence of health interventions [66] and to incorporate PA intervention studies in the sports context [67]. Based on our findings, we expect that a suggested framework could result in future effective health intervention programs with more validation. From our discussion, we propose three key themes that dominate the gamification strategies when using gamified WFT devices among participants in the reviewed studies. Based on the notion that there is a limited effort to examine the antecedents of PA engagement $[67,68]$, these three themes could be kick-starters to boost engagement levels.

In Lewis et al. [40], participants with an intermediate level of exercise were more likely to use challenges, competition/leaderboard, and rewards/badges than beginner or advanced groups. Furthermore, findings from Schaffarczyk and Ilhan's study [45] indicated a positive relationship between involvement levels and desire to compete against others. These findings suggest future work for sport scholars to test the role of PA involvement in appreciating gamification elements and in PA engagement.

Several studies also argued that different demographic groups may have different preferences of gamification elements [12,24,30]. Richter et al. [24] noted that gamification features might perform differently on individual users. Some users engaged more when they receive badges in exchange for hard work, while others may prefer social incentives. After surveying different age groups, Kappen et al. [12] suggested that it is critical to integrate extrinsic motivational affordances (e.g., badges, rewards) in the youngest groups, while the eldest group requires feedback elements (e.g., step counters, praise). Buchem et al. [30] also found that male users received more categories of badges than 
female users (e.g., likes, steps). Thus, future studies may need to test the influence of demographics on the perceptions of the gamification elements.

Since the pandemic, fitness activity has shifted from the gym to individual-based, at-home exercise training. Fitness platforms using mixed-reality and immersive virtual environment become highly popular [69]. Some examples of interactive health home fitness platforms are Mirror, Peloton, iFit, Zwift, etc. Thus, future research can explore the role of gamification in mixed reality and immersive virtual fitness platforms given the growth in demand of these platforms.

\section{Practical Implications and Limitations}

The WFT has become a top fitness trend, which provides new opportunities for industry applications and researchers, athletes, coaches, and endurance runners [70]. The device can also be a personal coach for individuals who have lower accessibility due to various psychological, social, or physical reasons [71]. The findings of our study provide several practical implications for WFT companies that could be utilized to meet the users' satisfaction and continuous usage. Some WFT companies and major marathon events partnered with each other (e.g., Fitbit and Miami marathon) and that partnership allows for sport event management implications in terms of designing event experiences. For example, creating social-based gamification interventions with the event participants could yield to more positive experiences and eventually more sustainable exercise behaviors. The WFT associates with social media tools or mobile applications, which can allow sport event participants to post narratives, numerical data, cheering messages, etc. During preparation for a running event, empowering participants to share their feelings and behaviors can maximize the benefits from the event experience. When participants notice that others exercise more, they may facilitate extrinsic motivation and PA engagement. Our discussions address the description of each gamification theme and the relationships that existed in the reviewed studies. The relationship may provide a direction for future studies.

There are some limitations of our study that need to be addressed. Firstly, our review did not use more systemic type of reviews due to a limited number of studies in fields. Additionally, our study is not designed to evaluate the quality of articles or assess the significance of the data. Thus, our discussions only address the description of each gamification theme and the relationships that existed in the reviewed studies. In addition, although we used various databases to synthesize our findings, there may be studies written in non-English sources or research design studies that were not reviewed.

Author Contributions: Conceptualization, I.C. and K.K.; methodology, I.C.; validation, I.C. and K.K.; investigation, I.C.; resources, I.C.; writing-original draft preparation, I.C.; writing-review and editing, I.C., K.K. and S.S.; visualization, I.C. and K.K.; supervision, K.K. and S.S.; project administration, I.C., K.K. and S.S.; funding acquisition, S.S. All authors have read and agreed to the published version of the manuscript.

Funding: This research received no external funding.

Conflicts of Interest: The authors declare no conflict of interest.

\section{References}

1. U.S. Department of Health and Human Services. 2018 Physical Activity Guidelines Advisory Committee Scientific Report. Available online: https:/ /health.gov/sites/default/files/2019-09/PAG_Advisory_Committee_Report.pdf (accessed on 3 February 2020).

2. The Centers for Disease Control and Prevention. 2008 Physical Activity Guidelines for Americans. Available online: https: //www.cdc.gov/physicalactivity/downloads/trends-in-the-prevalence-of-physical-activity-508.pdf (accessed on 17 March 2020).

3. Baker, B.J.; Zhou, X.; Pizzo, A.D.; Du, J.; Funk, D.C. Collaborative self-study: Lessons from a study of wearable fitness technology and physical activity. Sport Manag. Rev. 2017, 20, 114-127. [CrossRef]

4. Santini, S.; Galassi, F.; Kropf, J.; Stara, V.A. Digital coach promoting healthy aging among older adults in transition to retirement: Results from a qualitative study in Italy. Sustainability 2020, 12, 7400. [CrossRef] 
5. Wurmser, Y. Wearables 2019. Advanced Wearables Pick Up Pace as Fitness Trackers Slow. eMarketers.com. 2019. Available online: https:/ / www.emarketer.com/content/wearables-2019 (accessed on 3 January 2019).

6. Kundinger, T.; Sofra, N.; Riener, A. Assessment of the potential of wrist-worn wearable sensors for driver drowsiness detection. Sensors 2020, 20, 1029. [CrossRef] [PubMed]

7. Kerner, C.; Goodyear, V.A. The motivational impact of wearable healthy lifestyle technologies: A self-determination perspective on Fitbits with adolescents. Am. J. Health Educ. 2017, 48, 287-297. [CrossRef]

8. Lee, J.; Kim, D.; Ryoo, H.Y.; Shin, B.S. Sustainable wearables: Wearable technology for enhancing the quality of human life. Sustainability 2016, 8, 466. [CrossRef]

9. Zhao, Z.; Etemad, S.A.; Arya, A. Gamification of exercise and fitness using wearable activity trackers. In Proceedings of the 10th International Symposium on Computer Science in Sports (ISCSS); Springer: Cham, Switzerland, 2016; pp. 233-240. [CrossRef]

10. Ledger, D.; MacCaffrey, D. Inside Wearables: How the Science of Human Behavior Change Offers the Secret to Long-Term Engagement. Available online: https://medium.com/@endeavourprtnrs/inside-wearable-how-the-science-of-human-behaviorchange-offers-the-secret-to-long-term-engagement-a15b3c7d4cf3 (accessed on 21 April 2014).

11. Deterding, S.; Dixon, D.; Khaled, R.; Nacke, L. From game design elements to gamefulness: Defining gamification. In Proceedings of the 15th International Academic MindTrek Conference on Envisioning Future Media Environments; ACM: New York, NY, USA, 2011; pp. 9-15. [CrossRef]

12. Kappen, D.L.; Mirza-Babaei, P.; Nacke, L.E. Gamification through the application of motivational affordances for physical activity technology. In Proceedings of the Annual Symposium on Computer-Human Interaction in Play; ACM: New York, NY, USA, 2017; pp. 5-18. [CrossRef]

13. McCallum, S. Gamification and serious games for personalized health. In PHealth 2012; Blobel, B., Pharow, P., Sousa, F., Eds.; IOS Press BV: Amsterdam, The Netherlands, 2012; pp. 85-96. [CrossRef]

14. Zuckerman, O.; Gal-Oz, A. Deconstructing gamification: Evaluating the effectiveness of continuous measurement, virtual rewards, and social comparison for promoting physical activity. Pers. Ubiquitous Comput. 2014, 18, 1705-1719. [CrossRef]

15. Biddle, S.J.; Mutrie, N.; Gorely, T.; Faulkner, G. Psychology of Physical Activity: Determinants, Well-Being and Interventions, 4th ed.; Routledge: New York, NY, USA, 2021. [CrossRef]

16. Henriksen, A.; Mikalsen, M.H.; Woldaregay, A.Z.; Muzny, M.; Hartvigsen, G.; Hopstock, L.A.; Grimsgaard, S. Using fitness trackers and smartwatches to measure physical activity in research: Analysis of consumer wrist-worn wearables. J. Med. Int. Res. 2018, 20, e110. [CrossRef]

17. Pizzo, A.D.; Baker, B.J.; Jones, G.J.; Funk, D.C. Sport experience design: Wearable fitness technology in the health and fitness industry. J. Sport Manag. 2021, 35, 130-143. [CrossRef]

18. Huizinga, J. Homo Ludens: A Study of the Play-Element in Our Culture; Routledge \& Kegan Paul: London, UK, 1949.

19. Caillois, R. Man, Play, and Games; University of Illinois Press: Chicago, IL, USA, 2001.

20. Johnson, D.; Deterding, S.; Kuhn, K.A.; Staneva, A.; Stoyanov, S.; Hides, L. Gamification for health and wellbeing: A systematic review of the literature. Int. Interv. 2016, 6, 89-106. [CrossRef]

21. Sardi, L.; Idri, A.; Fernández-Alemán, J.L. A systematic review of gamification in e-Health. J. Biomed. Inform. 2017, 71, 31-48. [CrossRef]

22. Hamari, J.; Koivisto, J.; Sarsa, H. Does gamification work?-A literature review of empirical studies on gamification. In Proceedings of the 2014 47th Hawaii International Conference on System Sciences, Waikoloa, HI, USA, 6-9 January 2014; pp. 3025-3034. [CrossRef]

23. Deci, E.L.; Ryan, R.M. The general causality orientations scale: Self-determination in personality. J. Res. Pers. 1985, 19, 109-134. [CrossRef]

24. Richter, G.; Raban, D.R.; Rafaeli, S. Studying gamification: The effect of rewards and incentives on motivation. In Gamification in Education and Business; Springer: Cham, Switzerland, 2015; pp. 21-46. [CrossRef]

25. Kappen, D.L.; Nacke, L.E. The kaleidoscope of effective gamification: Deconstructing gamification in business applications. In Proceedings of the First International Conference on Gameful Design, Research, and Applications; Association for Computing Machinery: New York, NY, USA, 2013; pp. 119-122. [CrossRef]

26. Nicholson, S. A RECIPE for meaningful gamification. In Gamification in Education and Business; Reiners, T., Wood, L.C., Eds.; Springer: New York, NY, USA, 2015; pp. 1-20. [CrossRef]

27. Nicholson, S. Two paths to motivation through game design elements: Reward-based gamification and meaningful gamification. In iConference 2013 Proceedings; iSchools: Fort Worth, TX, USA, 2013; pp. 671-672. [CrossRef]

28. Ahn, S.J.; Johnsen, K.; Ball, C. Points-based reward systems in gamification impact children's physical activity strategies and psychological needs. Health Educ. Behav. 2019, 46, 417-425. [CrossRef]

29. Altmeyer, M.; Lessel, P.; Sander, T.; Krüger, A. Extending a gamified mobile app with a public display to encourage walking. In Proceedings of the 22nd International Academic Mindtrek Conference; ACM: New York, NY, USA, 2018; pp. 20-29. [CrossRef]

30. Buchem, I.; Merceron, A.; Kreutel, J.; Haesner, M.; Steinert, A. Gamification designs in wearable enhanced learning for healthy ageing. In 2015 International Conference on Interactive Mobile Communication Technologies and Learning (IMCL); IEEE: Thessaloniki, Greece, 2015; pp. 9-15. [CrossRef] 
31. Chen, X.S.; Changolkar, S.; Navathe, A.S.; Linn, K.A.; Reh, G.; Szwartz, G.; Patel, M.S. Association between behavioral phenotypes and response to a physical activity intervention using gamification and social incentives: Secondary analysis of the STEP UP randomized clinical trial. PLOS ONE 2020, 15, e0239288. [CrossRef]

32. Chen, Y.; Pu, P. HealthyTogether: Exploring social incentives for mobile fitness applications. In Proceedings of the Second International Symposium of Chinese Chi; ACM: New York, NY, USA, 2014; pp. 25-34. [CrossRef]

33. Chung, A.E.; Skinner, A.C.; Hasty, S.E.; Perrin, E.M. Tweeting to health: A novel mHealth intervention using Fitbits and Twitter to foster healthy lifestyles. Clin. Ped. 2017, 56, 26-32. [CrossRef]

34. Corepal, R.; Best, P.; O'Neill, R.; Tully, M.A.; Edwards, M.; Jago, R.; Hunter, R.F. Exploring the use of a gamified intervention for encouraging physical activity in adolescents: A qualitative longitudinal study in Northern Ireland. BMJ Open 2018, 8, e019663. [CrossRef]

35. Edney, S.; Ryan, J.C.; Olds, T.; Monroe, C.; Fraysse, F.; Vandelanotte, C.; Maher, C. User engagement and attrition in an app-based physical activity intervention: Secondary analysis of a randomized controlled trial. J. Med. Int. Res. 2019, 21, e14645. [CrossRef] [PubMed]

36. Fritz, T.; Huang, E.M.; Murphy, G.C.; Zimmermann, T. Persuasive technology in the real world: A study of long-term use of activity sensing devices for fitness. In Proceedings of the SIGCHI Conference on Human Factors in Computing Systems; ACM: Toronto, ON, Canada, 2014; pp. 487-496. [CrossRef]

37. Hayes, L.B.; Van Camp, C.M. Increasing physical activity of children during school recess. J. Appl. Behav. Anal. 2015, 48, 690-695. [CrossRef] [PubMed]

38. Jauho, A.M.; Pyky, R.; Ahola, R.; Kangas, M.; Virtanen, P.; Korpelainen, R.; Jämsä, T. Effect of wrist-worn activity monitor feedback on physical activity behavior: A randomized controlled trial in Finnish young men. Prev. Med. Rep. 2015, 2, 628-634. [CrossRef]

39. Kurti, A.N.; Dallery, J. Internet-based contingency management increases walking in sedentary adults. J. Appl. Behav. Anal. 2013, 46, 568-581. [CrossRef] [PubMed]

40. Lewis, Z.H.; Pritting, L.; Picazo, A.L.; JeanMarie-Tucker, M. The utility of wearable fitness trackers and implications for increased engagement: An exploratory, mixed methods observational study. Dig. Health 2020, 6, 59. [CrossRef]

41. Martin, S.S.; Feldman, D.I.; Blumenthal, R.S.; Jones, S.R.; Post, W.S.; McKibben, R.A.; Blaha, M.J. mActive: A randomized clinical trial of an automated mHealth intervention for physical activity promotion. J. Am. Heart Assoc. 2015, 4, e002239. [CrossRef] [PubMed]

42. Nelson, E.C.; Verhagen, T.; Noordzij, M.L. Health empowerment through activity trackers: An empirical smart wristband study. Comput. Hum Behav. 2016, 62, 364-374. [CrossRef]

43. Patel, M.S.; Benjamin, E.J.; Volpp, K.G.; Fox, C.S.; Small, D.S.; Massaro, J.M.; Manders, E.S. Effect of a game-based intervention designed to enhance social incentives to increase physical activity among families: The BE FIT randomized clinical trial. JAMA Int. Med. 2017, 177, 1586-1593. [CrossRef]

44. Patel, M.S.; Small, D.S.; Harrison, J.D.; Fortunato, M.P.; Oon, A.L.; Rareshide, C.A.; Kalra, P. Effectiveness of behaviorally designed gamification interventions with social incentives for increasing physical activity among overweight and obese adults across the United States: The STEP UP randomized clinical trial. JAMA Int. Med. 2019, 179, 1624-1632. [CrossRef]

45. Schaffarczyk, L.; Ilhan, A. Healthier Life and More Fun? Users' Motivations to Apply Activity Tracking Technology and the Impact of Gamification. In International Conference on Human-Computer Interaction; Springer: Cham, Switzerland, 2019; pp. 124-136. [CrossRef]

46. Seo, M.W.; Kim, Y.; Jung, H.C.; Kim, J.H.; Lee, J.M. Does online social connectivity promote physical activity in a wearable tracker-based intervention? A pilot randomized controlled study. Sustainability 2020, 12, 8803. [CrossRef]

47. Thorndike, A.N.; Mills, S.; Sonnenberg, L.; Palakshappa, D.; Gao, T.; Pau, C.T.; Regan, S. Activity monitor intervention to promote physical activity of physicians-in-training: Randomized controlled trial. PLoS ONE 2014, 9, e100251. [CrossRef]

48. Tong, X.; Gupta, A.; Gromala, D.; Shaw, C.D.; Neustaedter, C.; Choo, A. Utilizing gamification approaches in pervasive health: How can we motivate physical activity effectively? EAI End. Trans. Perv. Health Technol. 2017, 3, e3. [CrossRef]

49. Van Dantzig, S.; Bulut, M.; Krans, M.; van der Lans, A.; de Ruyter, B. Enhancing physical activity through context-aware coaching. In Proceedings of the 12th EAI International Conference on Pervasive Computing Technologies for Healthcare, New York, NY, USA, 21-24 May 2018; pp. 187-190. [CrossRef]

50. Walsh, G.; Golbeck, J. StepCity: A preliminary investigation of a personal informatics-based social game on behavior change. In CHI'14 Extended Abstracts on Human Factors in Computing Systems; ACM: New York, NY, USA, 2014; pp. 2371-2376. [CrossRef]

51. Washington, W.D.; Banna, K.M.; Gibson, A.L. Preliminary efficacy of prize-based contingency management to increase activity levels in healthy adults. J. Appl. Behav. Anal. 2014, 47, 231-245. [CrossRef]

52. Zhang, J.; Jemmott, J.B., III. Mobile app-based small-group physical activity intervention for young African American women: A pilot randomized controlled trial. Prev. Sci. 2019, 1, 1-10. [CrossRef]

53. Zhu, Y.; Dailey, S.L.; Kreitzberg, D.; Bernhardt, J. "Social networkout": Connecting social features of wearable fitness trackers with physical exercise. J. Health Commun. 2017, 22, 974-980. [CrossRef]

54. Latham, G.P.; Locke, E.A. Self-regulation through goal setting. Organ. Behav. Hum. Decis. Process. 1991, 50, 212-247. [CrossRef]

55. Greene, B.A.; Miller, R.B. Influences on achievement: Goals, perceived ability, and cognitive engagement. Contin. Educ. Programs Psychol. 1996, 21, 181-192. [CrossRef]

56. Bandura, A. Health promotion by social cognitive means. Health Educ. Behav. 2004, 31, 143-164. [CrossRef] 
57. Fitbit. Find Your Fit. Available online: https://www.fitbit.com/whyfitbit (accessed on 27 March 2020).

58. Consolvo, S.; Everitt, K.; Smith, I.; Landay, J.A. Design requirements for technologies that encourage physical activity. In Proceedings of the SIGCHI Conference on Human Factors in Computing Systems; ACM: New York, NY, USA, 2006; pp. 457-466. [CrossRef]

59. Ryan, R.M.; Deci, E.L. Self-determination theory and the facilitation of intrinsic motivation, social development, and well-being. Am. Psychol. 2000, 55, 68-78. [CrossRef]

60. Ashford, S.; Edmunds, J.; French, D.P. What is the best way to change self-efficacy to promote lifestyle and recreational physical activity? A systematic review with meta-analysis. Br. J. Health Psychol. 2010, 15, 265-288. [CrossRef]

61. Vassileva, J. Motivating participation in social computing applications: A user modeling perspective. User Mod. User-Adap. Int. 2012, 22, 177-201. [CrossRef]

62. Song, J.; Kim, J.; Cho, K. Understanding users' continuance intentions to use smart-connected sports products. Sport Manag. Rev. 2018, 21, 477-490. [CrossRef]

63. Gowin, M.; Wilkerson, A.; Maness, S.; Larson, D.J.; Crowson, H.M.; Smith, M.; Cheney, M.K. Wearable activity tracker use in young adults through the lens of social cognitive theory. Am. J. Health Educ. 2019, 50, 40-51. [CrossRef]

64. Zhou, R.; Kaplanidou, K. Building social capital from sport event participation: An exploration of the social impacts of participatory sport events on the community. Sport Manag. Rev. 2018, 21, 491-503. [CrossRef]

65. Deci, E.L.; Koestner, R.; Ryan, R.M. A meta-analytic review of experiments examining the effects of extrinsic rewards on intrinsic motivation. Psychol. Bull. 1999, 125, 627-668. [CrossRef] [PubMed]

66. Funk, D.; Jordan, J.; Ridinger, L.; Kaplanidou, K. Capacity of mass participant sport events for the development of activity commitment and future exercise intention. Leis. Sci. 2011, 33, 250-268. [CrossRef]

67. Henderson, K.A. A paradox of sport management and physical activity interventions. Sport Manag. Rev. 2009, 12, 57-65. [CrossRef]

68. Berg, B.K.; Warner, S.; Das, B.M. What about sport? A public health perspective on leisure-time physical activity. Sport Manag. Rev. 2015, 18, 20-31. [CrossRef]

69. Westmattelmann, D.; Grotenhermen, J.G.; Sprenger, M.; Rand, W.; Schewe, G. Apart we ride together: The motivations behind users of mixed-reality sports. J. Bus. Res. 2021, 134, 316-328. [CrossRef]

70. Wolters Kluwer. Wearables in Sports Medicine-Devices Play New Roles in Training and Treating Injuries in Runners. Available online: https:/ / www.newswise.com/articles/wearables-in-sports-medicine-devices-play-new-roles-in-training-and-treatinginjuries-in-runners (accessed on 12 December 2019).

71. Healthline. Turning Exercise into a Game Can Make Fitness More Fun and Effective. Available online: https://www.healthline. com/health-news/turning-exercise-into-a-game-can-make-fitness-more-fun-and-effective (accessed on 28 August 2019). 